http://dx.doi.org/10.18778/0860-6587.22.27

Grażyna Zarzycka

\title{
Radosław Kaleta, Polsko-bialoruska lapsologia glottodydaktyczna, Katedra Białorutynistyki, Wydział Lingwistyki Stosowanej, Warszawa 2015, ss. 178
}

Książka Radosława Kalety Polsko-białoruska lapsologia glottodydaktyczna jest to studium „poświęcone problematyce białorusko-polskich błędów glottodydaktycznych, czyli wpływowi języka białoruskiego na proces powstawania błędów glottodydaktycznych Białorusinów uczących się języka polskiego jako obcego" (Przedmowa autorska, s. 3).Glottodydaktyczne kontrastywne badania lapsologiczne mają w Polsce już dość długą tradycję, ale - tu należy zgodzić się z Autorem - nie były dotąd przeprowadzone poważne systemowe badania nad odziaływaniem języka białoruskiego na polskojęzyczne struktury przyswajane przez uczących się języka polskiego z Białorusi. Można więc mieć nadzieję, że rozprawa dra Kalety stanie się podstawowym przewodnikiem metodycznym dla nauczycieli języka polskiego zajmujących się kształceniem Białorusinów i Polaków z Białorusi. Trzeba tu dodać, że studenci z Białorusi są, obok studentów z Ukrainy, najliczniejszą grupą wśród studentów zagranicznych studiujących w Polsce. Ze względu na zastosowaną w rozprawie kontrastywną metodę badań praca Radosława Kalety będzie również przydatna podczas lektoratów języka białoruskiego w Polsce $\mathrm{Z}$ pracy tej będą mogli również z powodzeniem korzystać tłumacze obu języków.

Rozprawa ma przejrzystą, zwartą kompozycję. Autor konsekwentnie podąża tropem określonym już w mottach poprzedzających Wstęp (s.13), mówiących o tym, że: 1) popełnianie błędów jest rzeczą ludzką (nie można ich nie popełniać); 2) refleksja nad błędami jest dla osoby twórczej podstawą dalszego uczenia się. Osoba świadoma różnic między danymi językami będzie lepszym nauczycielem niż ta, która takiej świadomości nie ma. Podobnie rzecz się przedstawia w przypadku uczących się języków obcych. Ta teza jest bardzo czytelnie przedstawiona i przekonująco dowodzona przez Autora w poszczególnych fragmentach książki.

Praca składa się ze: Wstępu (s. 15-24), rozdziału I (s. 27-65), zawierającego przegląd literatury lapsologicznej, rozdziału II (s. 67-74), w którym Autor skrótowo omawia najważniejsze różnice między językami polskim i białoruskim a wreszcie kluczowego rozdziału III (s. 75-132), w którym proponuje typologię błędów „w ramach polsko-białoruskiej lapsologii glottodydaktycznej" (tytuł rozdziału), czyli na podstawie własnych badań, przeprowadzonych w środowisku białoruskim w latach 2008-2014, gdy pracował jako lektor języka polskiego na Wydziale Filologicznym Białoruskiego Uniwersytetu Państwowego w Mińsku. Autor przebadał 270 prac pisemnych różnego typu, które wyszły spod piór 130 uczących się na Białorusi języka polskiego. Dodatkowego materiału dostarczyły mu także badania prowadzone w Polsce metodą obserwacji uczestniczącej m. in. w czasie hospitacji zajęć w Centrum Języka Polskiego i Kultury Polskiej „Polonicum” Uniwersytetu Warszawskiego. Autor nie koncentrował się jedynie na środowisku studenckim. Materiał do badań zdobywał także podczas rozmów z pochodzącymi z Białorusi naukowcami, literatami, dziennikarzami, redaktorami i politykami, którzy w różnym stopniu władali polszczyzną; także wtedy, gdy po prostu przysłuchiwał się (np. podczas konferencji)

${ }^{1}$ grazyna.zarzycka@wp.pl; Katedra Lingwistyki Stosowanej i Kulturowej, Wydział Filologiczny, Uniwersytet Łódzki,90-236 Łódź, ul. Pomorska 171/173. 
ich wypowiedziom. W zakończeniu (s. 133-137) R. Kaleta podsumowuje wyniki swoich badań a w bogatej, różnojęzycznej bibliografii prac naukowych (s. 139-160) zestawia prace cytowane oraz uzupełniające i polecane. Rozprawę wieńczą jej streszczenia w języku polskim, białoruskim i angielskim (s. 161-178).

Jak czytamy we Wstępie (s. 17), „w niniejszej książce uwzględniono 515 błędów (127 błędów fonetycznych, 142 błędy ortograficzne, 9 błędów interpunkcyjnych, 122 błędy fleksyjne, 85 błędów składniowych, 26 błędów leksykalnych, 4 błędy słowotwórcze)”. Autor pisze dalej: „Błędy glottodydaktyczne tu omawiane stanowią próbę systematyzacji polsko-białoruskiej lapsologii glottodydaktycznej” (tamże), z czego wynika, że w korpusie badanych błędów znalazły się jedynie te, które wynikają z interferencji językowej. Zdaniem Kalety „można by wyróżnić co najmniej cztery grupy podstawowych błędów glottodydaktycznych” (tamże). Do pierwszej grupy zostały zaliczone „błędy wynikające z przenoszenia wyrazów i konstrukcji rosyjskich do języka polskiego”, do drugiej „[...] z nakładania języka białoruskiego na język polski”, do trzeciej: „, [... z z mechanicznego przyswajania języka obcego, przenoszenia w niewłaściwe miejsca form, które jako pierwsze nasuwają się użytkownikowi języka”; do czwartej , [...] z wpływów innych języków (interferencja języka obcego)" (s. 17-18). Twórca tej klasyfikacji zastrzega jednak, że ma ona charakter uproszczony. Pisze, że często pojawiają się błędy (do czego przyczynia się przede wszystkim dwujęzyczność mieszkańców Białorusi) przynależące jednocześnie do różnych grup. Autor uściśla też, że jego klasyfikacja dotyczy przede wszystkim błędów glottodydaktycznych, które zostały wychwycone w wypowiedziach Białorusinów posługujących się polszczyzną jako językiem obcym.

Białoruś, mimo sąsiedztwa z Polską, to dla Polaków w dużej mierze terra incognita. Autor monografii w dalszych fragmentach Wstępu opisuje panującą na Białorusi sytuację socjolingwistyczną i, mającą na nią wpływ, politykę językową rządu białoruskiego. Dowiadujemy się, że przyjęta na Białorusi w 1990 r. ustawa o językach - która nadawała białoruskiemu status jedynego języka urzędowego - została zmieniona z inicjatywy prezydenta Łukaszenki w 1996 r.; usankcjonowano wtedy oficjalnie funkcjonowanie na Białorusi języka rosyjskiego jako drugiego języka urzędowego, „co sprawiło, że w życiu codziennym białoruski został praktycznie wyeliminowany - jest zastępowany rosyjskim. Po białorusku więcej się pisze niż mówi. Używanie tego języka w sytuacjach codziennych jest traktowane jako coś nienaturalnego, jako akt obrony i propagandy, czasem jako zaczepka, prowokacja czy demonstracja" (s. 20). Posługiwanie się językiem białoruskim jest aktem politycznej odwagi - używają go białoruscy opozycjoniści, intelektualiści, niektórzy muzycy rockowi. Autor wymienia także stowarzyszenia, czasopisma, które promują lub kultywują używanie języka białoruskiego na Białorusi i na białostocczyźnie. Innym zjawiskiem językowym, o którym wspomina Kaleta, charakteryzując sytuację językową na Białorusi, jest używanie dwóch odmian potocznego języka białoruskiego: ustnego wariantu języka literackiego oraz używanej masowo tzw. trasianki, będącej nienormatywną mieszanką białoruskiego i rosyjskiego. Jak pisze Kaleta, „Białorusini używający wyłącznie języka rosyjskiego posługują się często właśnie trasianka”" (s. 22), która wypiera język białoruski, a „z drugiej strony [...] przez zwykłych ludzi bywa traktowana pozytywnie jako etap przejściowy z języka rosyjskiego do mniej znanego ojczystego - białoruskiego. Ludzie boją się robić błędy, czasem uważają, że nie sposób od razu zacząć mówić bezbłędnie po białorusku, stąd trasianka stanowi dla nich językową podporę, bezpieczną, komfortową i - w założeniu - czasową." 
Choć, jak twierdzi Autor, przedstawiane przez niego fakty są powszechnie znane Białorusinom, dla mnie stały się furtką otwierającą inne pozbawione stereotypów, myślenie o Białorusi.

Kończąc zawarte we Wstępie rozważania, Autor deklaruje, że jego podstawowym zadaniem badawczym było wychwycenie przede wszystkim błędów powstających za przyczyną nakładania się języka b i a ł o r u s k i e g o na język polski. Zdaniem Kalety, a także Guszczewej, którą cytuje, analizując zachowania studentów białoruskich uczących się polskiego, można zauważyć, że starając się być zrozumiałym przez Polaków, uczący się sięgną częściej po odpowiednik białoruski niż rosyjski, na co wpływ ma odczuwane przez nich większe podobieństwo między polskim a białoruskim niż polskim a rosyjskim. Zauważmy, że monografia Polsko-białoruska lapsologia dydaktyczna jest napisana przez autora znającego język białoruski i rosyjski, a więc takiego, który potrafi określić, który język jest odpowiedzialny za pojawienie się błędu w trakcie przyswajania polskiego.

W rozdziale I, dokonując przeglądu literatury przedmiotu, Autor koncentruje się najpierw na przestawieniu prac ogólnych, w których definiowane są błędy językowe, by w kolejnych fragmentach przejść do omówienia koncepcji teoretycznych tych badaczy, którzy zajmowali się definiowaniem i klasyfikacją błędów popełnianych w trakcie nauki języków obcych, w tym języka polskiego jako obcego; są wśród nich Franciszek Grucza, Witold Cienkowski, Hanna Komorowska, Aleksander Szulc, Grażyna Balkowska, Bożydar L. J. Kaczmarek, Krystyna Chomicz-Jung, Urszula Żydek-Bednarczuk, Ewa Lipińska, Anna Dąbrowska i Małgorzata Pasieka, Ryszard Jedliński. Kaleta omawia także definicje słownikowe błędu językowego oraz prace analityczne koncentrujące się szczególnie na błędach popełnianych przez użytkowników ,ze Wschodu” oraz na przewodnikach dla nauczycieli uczących języka polskiego jako obcego ,na Wschodzie”. Autor walczy z zakorzenionym w polskiej mentalności i literaturze naukowej stereotypem „Wschodu”. Nawołuje - i jest to postulat, z którym trzeba się zgodzić - do tworzenia podręczników do nauki języka polskiego przeznaczonych dla konkretnych grup narodowościowych, przy powstaniu których powinni współpracować poloniści krajowi i zagraniczni, będący ekspertami w zakresie danego języka.

W rozdziale II Autor zwięźle przedstawił najważniejsze rozbieżności między językiem białoruskim a polskim, ujawniając miejsca trudne. Skupił się tu na różnicach występujących w alfabecie, akcentowaniu, wymowie i pisowni niektórych samogłosek, spółgłosek i zbitek spółgłoskowych. Zwrócił uwagę na brak krótkich form zaimków w języku białoruskim, różnicach w zakresie pisowni cząstki „się” w obu językach, w użyciu wołacza i odmianie form czas przeszłego. Wyodrębnienie owych najważniejszych miejsc trudnych ma być przydatne nauczycielom przygotowującym się do nauczania polszczyzny w białoruskim środowisku językowym. Znając różnice i podobieństwa rzeczywiste i pozorne - między oboma językami, lektor będzie w stanie przygotować odpowiednie zestawy ćwiczeń, które zapobiegną błędom interferencyjnym. Autor poleca także, by przed kursem językowym ukazać owe kontrasty samym uczącym się, co „uczuli ich na pewne kwestie i wzmocni czujność. Być może zapobiegnie nawet nadmiernej generalizacji i zbyt pochopnemu przenoszeniu reguł jednego języka do drugiego, co jest częstym zjawiskiem, zwłaszcza gdy dotyczy języków blisko spokrewnionych" (s. 88 i 89).

Przedstawione w rozdziale III rezultaty badań własnych Autora to przeprowadzona z dużą wprawą analiza, zgodna z najlepszymi zasadami stosowanymi w lapsologii kontrastywnej. Autor omawia najbardziej typowe błędy językowe, dokonując ich podziału na: fonetyczne, ortograficz- 
ne, interpunkcyjne, fleksyjne, składniowe, leksykalne i słowotwórcze. Formy błędne zostały oznaczone gwiazdkami, obok zostały podane formy właściwe, jak też formy z języka wyjściowego, które spowodowały interferencję. W Zakończeniu znajdujemy podsumowanie wyników badań. Do problemów językowych sprawiających Białorusinom najwięcej kłopotów w trakcie nauki języka polskiego Autor zaliczył w zakresie fleksji rzeczowników - wybór właściwej końcówki w dopełniaczu i celowniku 1.p. rzeczowników w rodz. męskim, w zakresie odmiany czasowników: błędy w formach czasu przeszłego, polegające na nierozróżnianiu form męskoosobowych i niemęskoosobowych (-li; -ły). Licznie wystąpiły także błędy wynikające z odmiennej rekcji przyimkowej lub bezprzyimkowej czasowników w języku polskim i białoruskim. W korpusie błędów zebranych przez badacza najmniej było błędów frazeologicznych, co Autor tłumaczy przede wszystkim tym, że młodzi użytkownicy języka rzadko używają frazeologizmów. Jest to słuszna uwaga; podobne obserwacje mają dziś także badacze zajmujący się współczesną frazeologią polską.

We fragmentach wieńczących monografię Autor zgodził się z poglądami tych metodologów, którzy uważają, że w polu badań lapsologicznych powinny się znaleźć nie tylko błędy będące skutkiem negatywnego transferu językowego. Wśród interesujących zagadnień badawczych Kaleta wymienia m.in.: czynniki pozajęzykowe powodujące błędy glottodydaktyczne, relacja między metodami uczenia się i nauczania a błędami uczniowskimi. Jako zagadnienia warte głębszego przebadania uznał problem interferencji języka obcego w lapsologii polsko-białoruskiej, jak też wpływ nieznajomości realiów kultury docelowej na pojawienie się błędu w języku docelowym. Radosław Kaleta kończy swoją rozprawę o błędach popełnianych przez Białorusinów optymistycznie: „Trzeba jednak podkreślić, że Białorusini to specyficzna grupa uczących się języka polskiego. Szybko osiągają płynność językową i mają dobre rezultaty w nauce. Gdyby obcokrajowcy z innych krajów tak szybko i na tak wysokim poziomie opanowywali język polski, byłoby to naprawdę budujące” (s. 137).

Jestem przekonana, że ci lektorzy, którzy zapoznają się z rozprawą Radosława Kalety, będą cieszyć się jeszcze lepszymi niż zazwyczaj wynikami swojej pracy ze słuchaczami z Białorusi. 